\title{
Four families with immunodeficiency and chromosome abnormalities
}

\author{
D. C. A. CANDY, A. R. HAYWARD, D. T. HUGHES, L. LAYWARD, AND J. F. SOOTHILL \\ Departments of Immunology, Child Health, and Histopathology, Institute of Child Health, and The \\ Hospital for Sick Children, London
}

SUMMARY Six children, with severe deficiency of some or all of the immunoglobulins and minor somatic abnormalities, had chromosomal abnormalities: (1) 45,XY,t(13q/18q), (2) 46,XY,21ps +, (3) two brothers 46,XY (inv. 7), (4) 45,X,t(11p/10p)/46X,iXq,t(11p/10p) and, (5) in addendum, $45, \mathrm{XX},-18 ; 46, \mathrm{XX}, \mathrm{r} 18$. The chromosome abnormalities were detected in B- as well as T-lymphocytes (as evidenced by using both PHA- and PWM-stimulated cultures) in all probands, but one was mosaic in PHA culture, although all his PWM-stimulated cells were abnormal. Chromosomal variants were also detected in relatives of three and immunodeficiency in relatives of two.

Only two firm associations between immunodeficiency and autosomal chromosome abnormality in phytohaemagglutinin (PHA) stimulated Tlymphocytes are recognised. Some patients with ataxia telangiectasia show general chromosome instability with many spontaneous breaks (especially of chromosome 14 and other D-group chromosomes) (Nelson et al., 1975; Oxford et al., 1975). IgA deficiency is sometimes associated with chromosome 18 abnormalities-deletions of short and long arm (Feingold et al., 1969; Faed et al., 1972), ring forms (Finley et al., 1968), and large chromosomes (Yanagisawa, 1972). There are also reports of immunodeficient patients with other chromosomal abnormalities (Jacobs et al., 1968; Kretschmer et al., 1968; Calvani et al., 1976), especially of the D-group. We studied the chromosomes in four immunodeficient children who had unusual facies; each had an abnormality.

As the immunodeficiency was of antibody we studied the chromosomes not only in PHA-stimulated lymphocytes (predominantly T-lymphocytes), but also in pokeweed mitogen- (PWM) stimulated lymphocytes (which include B-lymphocytes).

\footnotetext{
Institute of Child Health

Department of Immunology

J. F. SOOTHILL, professor of immunology

L. LAYWARD, senior medical laboratory scientific officer

Department of Child Health

D. C. A. CANDY, research fellow

Department of Histopathology

D. T. HUGHES, senior lecturer in cytogenetics

Department of Pediatrics, University of Colorado Medical

Center, Denver, Colorado, USA

A. R. HAYWARD, associate professor of pediatrics
}

\section{Methods}

Immunoglobulins were measured by radial diffusion (Fahey and McKelvey, 1965). Lymphocyte thymidine uptake after PHA stimulus, E-rosette count, and surface immunofluorescence were by the method of Espanol et al. (1974). Chromosomal analysis of PHA-stimulated lymphocytes after colcemid treatment was by the method of Hungerford (1965).

For chromosomal analysis $0.05 \mathrm{ml}$ PWM (Gibco, New York) was added to $5 \mathrm{ml}$ cultures (Wybran et al., 1973).

T- and B-enriched preparations of lymphocytes were prepared by rosetting techniques from Case 1 and a healthy donor, cocultured with PWM, and tested for cytoplasmic immunofluorescence for immunoglobulin (Hayward and Lawton, 1977).

Buccal smears for X-chromatin studies were prepared by a modification of the method of Klinger and Ludwig (1957). Hydrolysis in $1 \mathrm{~mol} / 1 \mathrm{HCL}$ for 8 minutes was followed by staining for 10 minutes in $2 \%$ aqueous toluidine blue.

Family 1. Case 1, a boy, was investigated soon after birth because his maternal uncle had had life-long immunoglobulin deficiency (he died before the proband's birth). At birth Case 1 had limb swelling, deformed toe nails, spindle shaped fingers, microcephaly, and an unusual facies with fullness over the maxillary and mandibular bones. Immunoglobulin deficiency was found (see below) and replacement treatment was started, although he had had no obvious infection. At 15 months he developed convulsions, up to five a day. Several members of his 
father's family had had convulsions. Neutropenia was noted once. Levels of serum IgG, IgA, and IgM have been persistently very low. Lymphocyte count was normal with normal E-rosette count, and a high percentage positive for surface immunoglobulin immunofluorescence (Table). Chromosome analysis of PHA-stimulated cells showed a normal/translocation mosaic; 3 of 10 cells studied were normal;

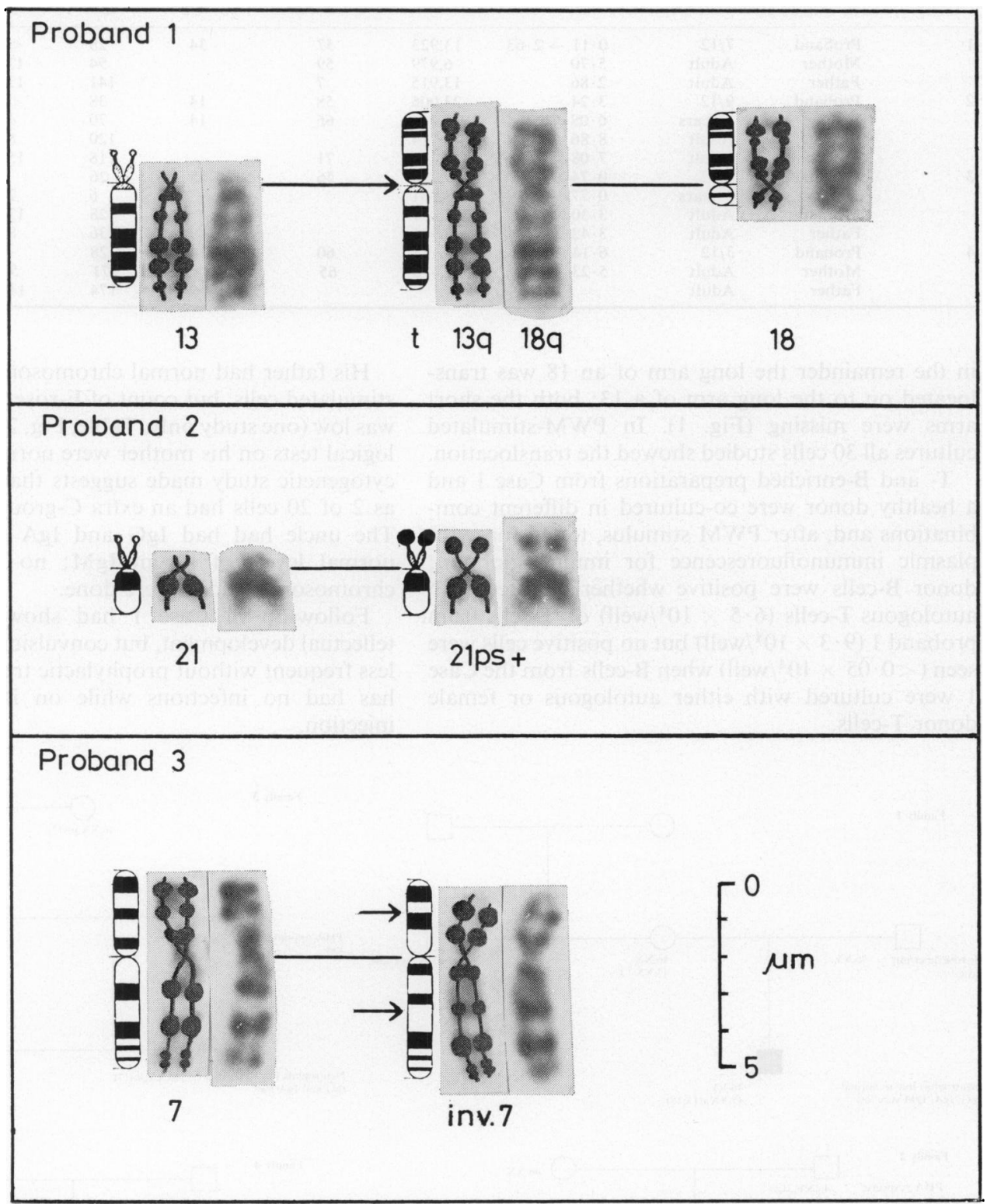

Fig. 1 (scale in microns). Anomalous chromosome pairs from probands 1, 2, and 3. Photomicrographs of the normal and abnormal member of each affected chromosome pair are shown, in each patient, together with a drawing and the standard international diagram of the banding pattern (Paris Conference, 1972). Translocated chromosome in proband 1 (a mosaic) was formed by fusion of chromosomes 13 and 18, after loss of their short arms by breakage at the centromere (arrowed). Proband 2 has large satellites on chromosome 21. In proband 3, the arrows pointing to the inverted chromosome 7 (inv. 7) indicate the apparent breakage points at which the order of the bands has been reversed. 
Table Immunological data on patients with immunoglobulin deficiency and chromosomal abnormalities. Lymphocyte PHA response is expressed in maximum DPM $/ 0.01 \mathrm{ml}$ whole blood. Lymphocyte forming rosettes with sheep red cells $(E-R F C)$ and with surface immunoglobulin $\left(S I g^{+}\right)$are expressed as \%

\begin{tabular}{|c|c|c|c|c|c|c|c|c|c|}
\hline \multirow[t]{2}{*}{ Family } & \multirow[t]{2}{*}{ Subject } & \multirow[t]{2}{*}{ Age } & \multirow{2}{*}{$\begin{array}{l}\text { Neutrophils } \\
\left(\times 10^{9} / l\right)\end{array}$} & \multirow{2}{*}{$\begin{array}{l}\text { PHA } \\
\text { response }\end{array}$} & \multicolumn{2}{|c|}{ Lymphocyte \% } & \multicolumn{3}{|c|}{ Serum $(I U / m l)$} \\
\hline & & & & & $E-R F C$ & $S \operatorname{Sg}^{+}$ & $\operatorname{Ig} G$ & $\operatorname{Ig} A$ & $\operatorname{Ig} M$ \\
\hline \multirow[t]{3}{*}{1} & Proband & $7 / 12$ & $0.11 \rightarrow 2 \cdot 63$ & 13,923 & 57 & 34 & 28 & $<3$ & $<3$ \\
\hline & Mother & Adult & $5 \cdot 70$ & 6,979 & 59 & & 94 & 123 & 193 \\
\hline & Father & Adult & $2 \cdot 86$ & 13,915 & 7 & & 141 & 135 & 193 \\
\hline \multirow[t]{4}{*}{2} & Proband & $9 / 12$ & $3 \cdot 24$ & 23,006 & 58 & 14 & 38 & $<3$ & 26 \\
\hline & Sibling & 4 years & $6 \cdot 08$ & 22,454 & 66 & 14 & 70 & 40 & 72 \\
\hline & Mother & Adult & $8 \cdot 86$ & 14,914 & & & 120 & 84 & 192 \\
\hline & Father & Adult & $7 \cdot 08$ & 3,162 & 71 & & 118 & 151 & 86 \\
\hline \multirow[t]{4}{*}{3} & Proband & $4 / 12$ & $0.74-6.03$ & 29,290 & 56 & 15 & 26 & 3 & $43 \rightarrow 104$ \\
\hline & Sibling & 3 years & 0.77 & 3,861 & & & 6 & 24 & $>170$ \\
\hline & Mother & Adult & $3 \cdot 30$ & 2,057 & & & 128 & 132 & 312 \\
\hline & Father & Adult & $3 \cdot 42$ & 5,945 & & & 136 & 88 & 208 \\
\hline \multirow[t]{3}{*}{4} & Proband & $3 / 12$ & $6 \cdot 14$ & 4,135 & 60 & 14 & 28 & 9 & 106 \\
\hline & Mother & Adult & $5 \cdot 23$ & 2,478 & 65 & 11 & 171 & 59 & 261 \\
\hline & Father & Adult & & & & & 174 & 149 & 128 \\
\hline
\end{tabular}

in the remainder the long arm of an 18 was translocated on to the long arm of a 13 ; both the short arms were missing (Fig. 1). In PWM-stimulated cultures all 30 cells studied showed the translocation.

T- and B-enriched preparations from Case 1 and a healthy donor were co-cultured in different combinations and, after PWM stimulus, tested for cytoplasmic immunofluorescence for immunoglobulin; donor B-cells were positive whether cultured with autologous T-cells $\left(6 \cdot 5 \times 10^{4} /\right.$ well $)$ or T-cells from proband $1\left(9 \cdot 3 \times 10^{4} /\right.$ well $)$ but no positive cells were seen $\left(<0.05 \times 10^{4} /\right.$ well $)$ when B-cells from the Case 1 were cultured with either autologous or female donor T-cells.
His father had normal chromosomes in all PHAstimulated cells, but count of E-rosette-forming cells was low (one study only, Table, Fig. 2). The immunological tests on his mother were normal, but the one cytogenetic study made suggests that she is mosaic, as 2 of 20 cells had an extra C-group chromosome. The uncle had had IgG and IgA deficiency with normal levels of serum IgM; no lymphocyte or chromosome studies were done.

Follow-up of Case 1 had shown retarded intellectual development, but convulsions have become less frequent without prophylactic treatment, and he has had no infections while on immunoglobulin injection.
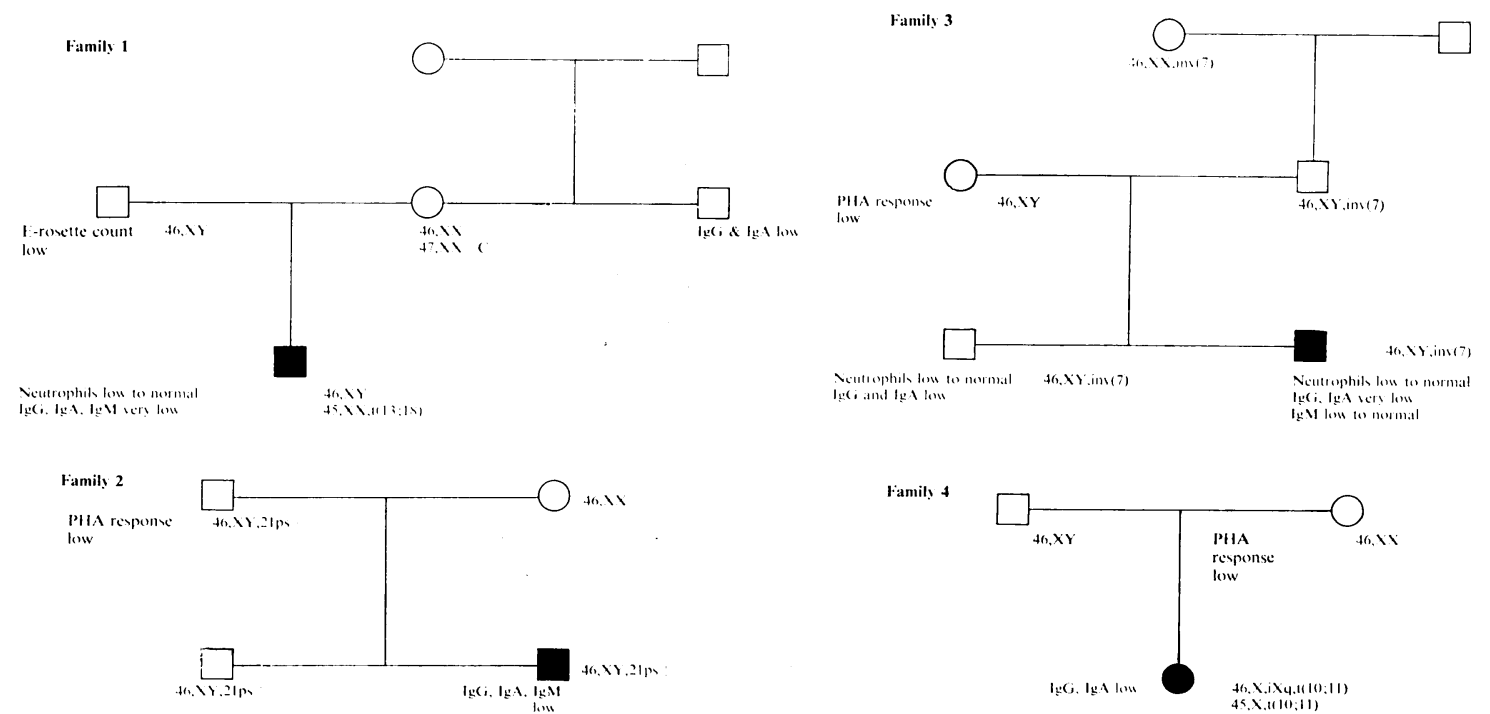

Fig. 2 Family trees of 4 probands $(\bullet)$ with abnormalities of chromosomes and immunoglobulins. Abnormal immunological findings and results of chromosome analysis of PHA-stimulated lymphocyte cultures are given. 
Family 2. Case 2, a 9-month-old boy, was investigated for growth retardation, developmental delay, and repeated febrile illnesses with convulsions. He had an unusual facies, with a mongoloid slant to the eyes, hypertelorism, anteverted nares, and broad upper lip. He had hyperextensible joints and pigmented naevi on the occiput, thigh, and axilla. A cystogram showed bilateral ureteric reflux with parenchymal opacification of the left kidney. His head was asymmetric and a CAT scan showed cortical thinning, especially of the frontal lobes. There was evidence of respiratory and urinary infections.

Levels of serum IgG, IgA, and IgM were all very low. Salivary $\operatorname{IgA}$ and isohaemagglutinins were absent. Chromosome analysis of both PHA- and PWM-stimulated lymphocytes showed that all cells had a giant satellite on the short arm of chromosome 21 (Fig. 1). He has since had occasional mild respiratory infections while on prophylactic cotrimoxazole, and his convulsions are well controlled on sodium valproate; his psychomotor development is retarded.

His mother's immunological tests were normal, as were her chromosomes. Both his father and 4year-old brother were well, but show the same chromosome aberration in all PHA- and PWMstimulated cells. Although the brother is immunologically normal, his father has a low PHA response (Table).

Family 3. Case 3, a 4-month-old boy, was investigated for growth retardation and feeding difficulties. He had an unusual facies, with a low set left ear, antimongoloid slant to the eyes, and high arched palate. He was wasted and breathless. Pneumocystis carinii infection was diagnosed on lung aspiration and Giardia lamblia were found in the faeces. He had intermittent neutropenia and low levels of $\mathrm{IgG}$ and IgA. IgM was low but rose to normal. The anti-A isoagglutinin titre was $1 / 1$. Salivary $\operatorname{IgA}$ was not detected. There was pericentric inversion of chromosome 7 on all cells on PHA and PWM cultures (this had previously been identified in PHA culture by Dr N. Gregson). He gained weight after treatment with immunoglobulin injections, co-trimoxazole, and metronidazole.

His mother had a low PHA response, but her other immunological tests and her chromosomes were normal. His paternal grandmother, father, and 4-year-old brother each showed the same chromosome abnormality. His father was well and immunologically normal. His brother had neutropenia on one occasion and has low levels of serum $\operatorname{IgG}$ and IgA. He was relatively well until recently apart from mild oral ulceration; this is now severe and immunoglobulin treatment has been started.
Family 4. Case 4, a 3-month-old girl, was investigated for growth retardation, prolonged hypocalcaemia (until 9 weeks old), and frequent infections: chronic oral and perineal candidiasis, chronic paronychia and pulp space infection, and septic arthritis of the hip. She had an unusual facies with micrognathia, high arched palate, and epicanthic folds. Pectus excavatum, widely spaced nipples, stridor, large umbilical hernia, hypotonia, anterior bowing of tibiae, and dystrophic nails were noted. Barium meal showed malrotation of the intestine.

Serum IgG and IgA were low and salivary IgA was not detected. E-rosette-forming cells, PHA response, and surface immunoglobulin immunofluorescence were normal. Of 20 cells studied, on PHA stimulus, 9 had a single $\mathrm{X}$-chromosome $(45, X)$ and 11 had an isochromosome for the long arms of $X$-that is she was a mosaic (Fig. 3). All lymphocytes showed an extra band on the short arm of chromosome 10 , and a missing band from the short arm of chromosome 11. PHA and PWM cultures gave similar results. Of 300 buccal cells $16 \%$ showed Barr bodies (normal female range 15 to $30 \%$ ); some were abnormally large. Her parent's chromosomes were normal; the mother's PHA response was low.

She has had no subsequent serious infections and serum calcium has remained normal without further treatment, but there is evidence of psychomotor retardation.

\section{Discussion}

The association of immunoglobulin deficiency with chromosome aberrations and abnormalities raises a number of possibilities. It may be coincidental as autosomal abnormalities are found in about $0.3 \%$ of newborn babies (Evans, 1977), and we are becoming increasingly aware that immunodeficiency is not rare. The occurrence of both in a single individual will be an occasional chance finding, but the detection by chance of a significant chromosomal abnormality or variation in all four probands we studied would be a very odd run of luck. It is possible that the structural and chromosomal abnormalities were causatively associated, and immunodeficiency, which brought them to our attention, was associated by chance.

The other possibilities for the association are that the chromosome abnormality may cause the immunodeficiency, or that the immunodeficiency may have led to abnormal handling of an intra- or extrauterine viral infection by the child or the mother which might have caused the chromosome abnormality, or that both were caused by the same environmental factor, for instance by a virus infection (Soothill et al., 1966). There is no history 


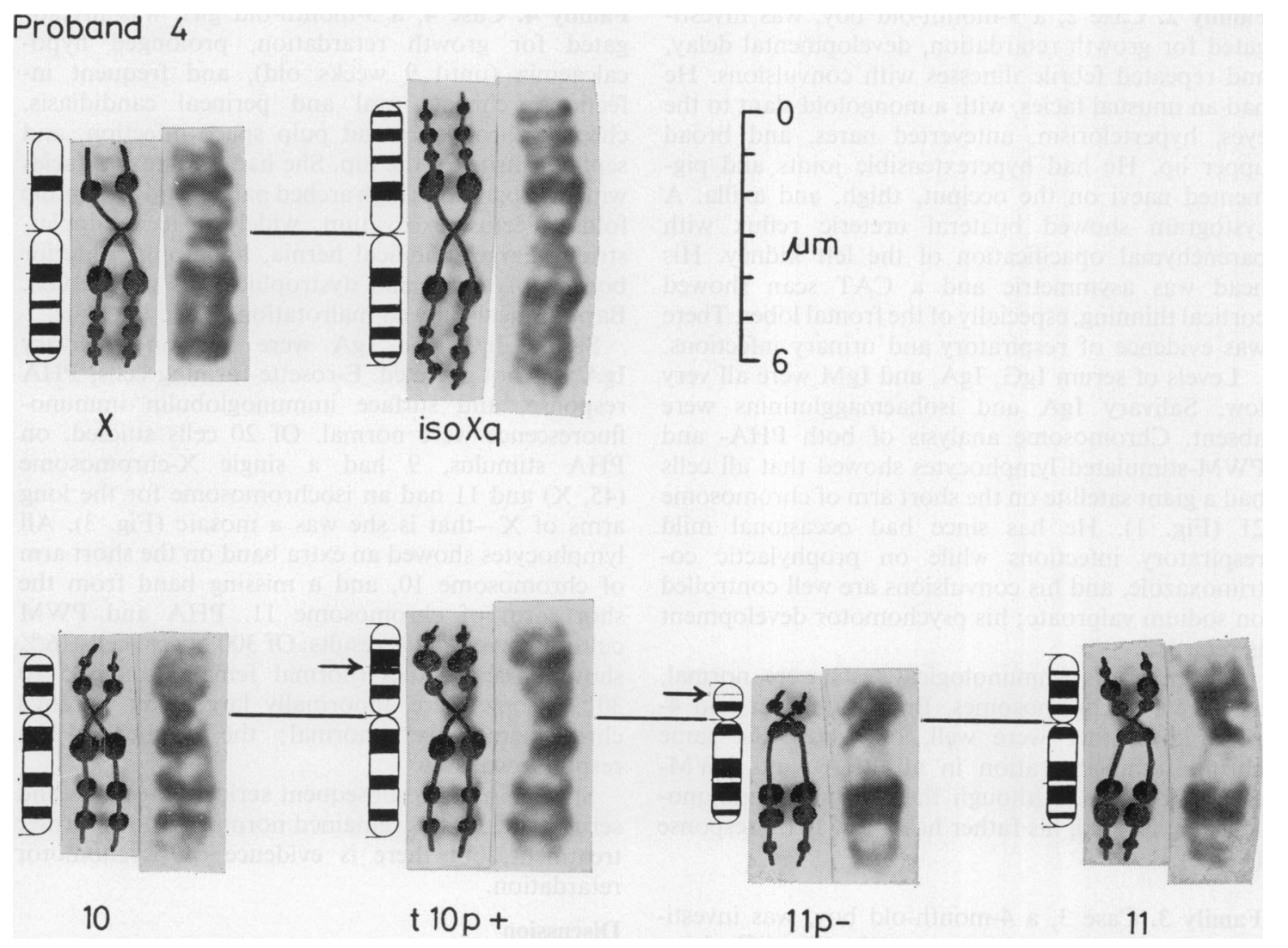

Fig. 3 (scale in microns). Anomalous chromosome pairs from proband 4, presented in the same way as in Fig. 1 . In addition to the normal $X$ and iso Xq (with its duplicated long arm), there are two abnormal autosomes which seem to be balanced for a translocation between chromosomes 10 and 11 . Arrows indicate the apparent breakage points at which part of the short arm of an 11 broke off to become attached to the short arm of a 10.

of overt viral infection during pregnancy in any of these families. It is very likely that the mechanism of the associations may be different in the different families. In families 2 and 3 it is more likely that they were coincidental as the chromosome abnormality was detected in an immunologically and structurally normal member of both families, but one cannot exclude the possibility that the abnormalities resulted from varying expression of the chromosome defect. The neutropenia in association with inversion of chromosome 7 in Case 3 is interesting in view of the report by Rowley (1973) of neutropenia with deletions of this chromosome. The known involvement of X-chromosome with immunoglobulin concentration (Butterworth et al., 1967; Rhodes et al., 1969) gives added significance to the finding in Case 4.

Although the family tree (Fig. 2) in family 1 suggests $X$-linkage, neither the normal IgM in the uncle, nor the normal number of lymphocytes with surface immunoglobulin in the child is consistent with X-linked agammaglobulinaemia, but there probably are other forms of X-linked immunodeficiency. Coincidental chromosomal abnormality with such an immunodeficiency must be considered, but there is evidence in favour of a causative relationship. The mosaicism of the T-lymphocytes (with apparently normal $\mathrm{T}$-cell function, including that of co-operation) but the consistent chromosomal abnormality in the PWM-stimulated cultures, many of which would be B-lymphocytes which were functionally defective in vitro and in vivo would be an additional coincidence if the relationship were not causal.

The chromosomes affected in Case 1 have been 
previously associated with immunodeficiencychromosome 18 with IgA deficiency (Feingold et al., 1969; Faed et al., 1972), and group- D chromosomes with IgM deficiency (Kretschmer et al., 1968), and severe combined immunodeficiency (Calvani et al., 1976). An association between swollen feet and chromosome 18 abnormality has been described (Vianna-Morgante et al., 1976) without immunological data. Perhaps there was a generalised genetic predisposition to chromosome instability involving the C-group defect in the mother, the 13/18 in the child, and one which we can only guess at in the uncle, causing the immunodeficiency.

Cytogenetic study of both PHA- and PWMstimulated cultures permits study of variation of mosaicism in different cell populations and organspecific cell selection. Full interpretation of these relationships demands more data, but if such associations are found consistently, they may throw light on the chromosome distribution of genes which control immunity mechanisms, other than those already described.

\section{Addendum}

Since completing this paper we have observed a child with a ring 18-chromosome, who showed the somatic abnormalities and IgA deficiency similar to the child described by Finley et al. (1968). Our patient was mosaic for this abnormality ( 3 cells 45 , XX, -18 ; 17 cells $46, X X, r$ 18).

We are grateful to Dr N. Gregson who first observed the chromosomal abnormalities in family 3 , to $\mathrm{Dr}$ J. Stewart for help with studies on family 4 , to Professor $\mathrm{O}$. Wolff and Dr J. T. Harries under whose care the probands were admitted, and to Miss Doreen M. Farrington and Mrs Janette D. O'Connell for technical help.

\section{References}

Butterworth, M., McClellan, B., and Allansmith, M. (1967). Letter: Influence of sex on immunoglobulin level. Nature, 214, 1224-1225.

Calvani, M., Franchi, F., and Aiuti, F. (1976). Letter: Severe combined immunodeficiency and trisomy D. Archives of Disease in Childhood, 51, 485.

Espanol, T., Todd, G. B., and Soothill, J. F. (1974). The effect of anaesthesia on the lymphocyte response to phytohaemagglutinin. Clinical and Experimental Immunology, 18, 73-79.

Evans, H. J. (1977). Chromosome anomalies among live births. Journal of Medical Genetics, 14, 309-312.

Faed, M. J. W., Whyte, R., Paterson, C. R., McCathie, M., and Robertson, J. (1972). Deletion of the long arms of chromosome $18(46, \mathrm{XX}, 18 \mathrm{q}-)$ associated with absence of
IgA and hypothyroidism in an adult. Journal of Medical Genetics, 9, 102-104.

Fahey, J. L., and McKelvey, E. M. (1965). Quantitative determination of serum immunoglobulins in antibodyagar plates. Journal of Immunology, 94, 84-90.

Feingold, M., Schwartz, R. S., Atkins, L., Anderson, R., Bartsocas, C. S., Page, D. L., and Littlefield, J. W. (1969). IgA deficiency associated with partial deletion of chromosome 18. American Journal of Diseases of Children, 117, 129-136.

Finley, S. C., Finley, W., Noto, T. A., Uchida, I. A., and Roddam, R. F. (1968). Letter: IgA absence associated with a ring-18 chromosome. Lancet, 1, 1095-1096.

Hayward, A. R., and Lawton, A. R. (1977). Induction of plasma cell differentiation of human fetal lymphocytes; evidence for functional immaturity of $T$ and $B$ cells. Journal of Immunology, 119, 1213-1217.

Hungerford, D. A. (1965). Leukocytes cultured from small inocula of whole blood and the preparation of metaphase chromosomes by treatment with hypotonic $\mathrm{KCl}$. Stain Technology, 40, 333-338.

Jacobs, J. C., de Capoa, A., McGilvray, E., Morse, J. H., Schullinger, J. N., Blanc, W. A., Heird, W. C., Miller, O. J., Rossen, R. D., and Walzer, R. A. (1968). Complement deficiency and chromosomal breaks in a case of Swiss-type agammaglobulinaemia. Lancet, 1, 499-503.

Klinger, H. P., and Ludwig, K. S. (1957). A universal stain for the sex chromatin body. Stain Technology, 32, 235-244.

Kretschmer, R., Janeway, C. A., and Rosen, F. S. (1968). Immunologic amnesia. Pediatric Research, 2, 7-16.

Nelson, M. M., Blom, A., and Arens, L. (1975). Letter: Chromosomes in ataxia-telangiectasia. Lancet, 1, 518-519.

Oxford, J. M., Harnden, D. G., Parrington, J. M., and Delhanty, J. D. A. (1975). Specific chromosome aberrations in ataxia-telangiectasia. Journal of Medical Genetics, 12, 251-262.

Paris Conference (1972). Conference on Standardisation in Human Cytogenetics, Paris, 1971. Birth Defects Original Article Series, volume 8, No. 7. March of Dimes: New York.

Rhodes, K., Markham, R. L., Maxwell, P. M., and MonkJones, M. E. (1969). Immunoglobulins and the X-chromosomes. British Medical Journal, 3, 439-441.

Rowley, J. D. (1973). Letter: Deletions of chromosome 7 in haematological disorders. Lancet, 2, 1385-1386.

Soothill, J. F., Hayes, K., and Dudgeon, J. A. (1966). The immunoglobulins in congenital rubella. Lancet, 1, 13851388.

Vianna-Morgante, A. M., Nozaki, M. J., Ortega, C. C., Coates, V., and Yamamura, Y. (1976). Partial monosomy and partial trisomy 18 in two offspring of carrier of pericentric inversion of chromosome 18. Journal of Medical Genetics, 13, 366-370.

Wybran, J., Chantler, S., and Fudenberg, H. H. (1973). Isolation of normal $\mathrm{T}$ cells in chronic lymphatic leukaemia. Lancet, 1, 126-129.

Yanagisawa, S. (1972). Immunoglobulin abnormality in a girl with a large chromosome 18. Journal of Medical Genetics, 9, 360-365.

Correspondence to Professor J. F. Soothill, Institute of Child Health, Department of Immunology, 30 Guilford Street, London WC1N 1EH.

Received 19 December 1978 